\title{
FRACTURE TOUGHNESS MEASUREMENTS WITH SUBSIZE DISK COMPACT SPECIMENS*
}

\author{
David J. Alexander \\ Metals and Ceramics Division \\ OAK RIDGE NATIONAL. LABORATORY \\ 4500S, MS-6151, P.O. BOX 2008 \\ Oak Ridge, TN 37831-6151
}

- Research sponsored by the Office of Fusion Energy, U.S. Department of Energy, under contract DE-AC05-840R21400 with Martin Marietta Energy Systems, Inc.

\begin{abstract}
The submitted manuscript has been authored by a contractor of the U.S. Government under contract No. DE-ACO5-840R21400. Accordingly, the U.S. Government retains nonexchrive, royalty-tree ficense to publish or reproduce the published form of this contribution, or allow others to do so, for U.S. Government purposes.
\end{abstract}

\section{DISCLAIMER}

This report was prepared as an account of work sponsored by an agency of the United States Government. Neither the United States Government nor any agency thereof, nor any of their employees, makes any warranty, express or implied, or assumes any legal liability or responsibility for the accuracy, completeness, or usefulness of any information, apparatus, product, or process disclosed, or represents that its use would not infringe privately owned rights. Reference herein to any specific commercial product, process, or service by trade name, trademark, manufacturer, or otherwise does not necessarily constitute or imply its endorsement, recommendation, or favoring by the United States Government or any agency thereof. The views and opinions of authors expressed herein do not necessarily state or reflect those of the United States Government or any agency thereof. 


\section{DISCLAIMER}

Portions of this document may be illegible in electronic image products. Images are produced from the best available original document. 


\title{
FRACTURE TOUGHNESS MEASUAEMENTS WITH \\ SUBSIZE DISK COMPACT SPECIMENS
}

\author{
David J. Alexander \\ Metals and Ceramics Division \\ Oak Ridge National Laboratory \\ 4500S, MS-6151, P.0. Box 2008 \\ Oak Ridge, TN 37831-6151
}

\begin{abstract}
Special fixtures and test methods have been developed for testing small disk compact specimens $(12.5 \mathrm{~mm}$ diam by $4.6 \mathrm{~mm}$ thick). Specimens of European type $316 \mathrm{~L}$ austenitic stainless steel were irradiated to damage levels of about $3 \mathrm{dpa}$ at nominal irradiation temperatures of either 90 or $250^{\circ} \mathrm{C}$ and tested over a temperature range from 20 to $250^{\circ} \mathrm{C}$. The results show that irradiation to this dose level at these temperatures reduces the fracture toughness but the toughness remains quite high. The toughness decreases as the test temperature increases. Irradiation at $250^{\circ} \mathrm{C}$ is more damaging than at $90^{\circ} \mathrm{C}$, causing larger decreases in the fracture toughness. The testing shows that it is possible to generate useful fracture toughness data with the small disk compact specimens.
\end{abstract}

\section{INTRODUCTION}

Candidate materials are being evaluated for the first-wall structure in the International Thermonuclear Experimental Reactor (ITER). Current estimates of the operating temperatures indicate that the structure will operate below about $300^{\circ} \mathrm{C}$. One of the materials proposed for the first wall is type 316 austenitic stainless steel. Very little information is available on the effects of irradiation at these low temperatures on the mechanical properties of austenitic stainless steels, particularly the fracture toughness $[1,2]$. Therefore, work is under way at Oak Ridge National Laboratory (ORNL) to measure the effect of irradiation on the fracture toughness of a variety of austenitic stainless steels. Three capsules have been designed, fabricated, and irradiated to dose levels of approximately $3 \mathrm{dpa}$; this approaches the expected accumulated dose at the end of the physics or basic phase of operation of ITER. The helium concentration generated as a result of transmutation of nickel was about 50 appm; this is in the range expected for the ITER first wall blanket and shield structure after a neutron exposure of about $3 \mathrm{dpa}$. These capsules were designed for irradiation temperatures of either 60 to $125^{\circ} \mathrm{C}$ (capsules HFIR-JP-18 and -19 ) or 250 to $300^{\circ} \mathrm{C}$ (HFIR-JP-17) [3-5]. All of the capsules have been successfully irradiated and disassembled. The complete results of the testing [6-8] and a full description of the testing methods [9] 
have been presented elsewhere. This paper describes some of the techniques that have been developed for this testing, and presents some results obtained with the European reference heat of type 316L stainless steel (EC316L).

\section{TEST METHODS}

The irradiations for these experiments were conducted at the High-Flux Isotope Reactor (HFIR) at ORNL due to the reactor availability and the high flux present in the HFIR target region. However, achieving the necessary low irradiation temperatures $\left(90\right.$ and $\left.250^{\circ} \mathrm{C}\right)$ placed severe restrictions on the specimen geometry. The gamma heating from the high-flux irradiation and the limited cooling available from the reactor cooling water required a very small specimen size to attain the lowest irradiation temperature. To use the HFIR target region efficiently, it was necessary to adopt a circular specimen geometry for the fracture toughness specimens. Therefore, the disk compact specimen geometry was chosen. This is an accepted specimen geometry for $\mathrm{K}_{\mathrm{lc}}$ measurements (ASTM Standard Test Method for Plane-Strain Fracture Toughness of Metallic Materials, E 399-90I, but is not yet included in the standards for J-integral-resistance (J-R) curve testing (ASTM Standard Test Method for $J_{1 c}$, A Measure of Fracture Toughness, E 813-89, or ASTM Standard Test Method for Determining J-R Curves, E 1152-87). These standards presently allow only conventional rectangular compact specimens or bend bars; however, the disk and rectangular compact specimens are very similar in geometry, and J-R data can be correctly determined from each if the appropriate compliance expressions are used. Preliminary experiments [10] indicated that useful data could be generated in the laboratory from small disk compact specimens.

The heat transfer calculations performed at ORNL and the size limitations imposed by the HFIR target region characteristics resulted in the selection of a specimen diameter and thickness of 12.5 and $4.63 \mathrm{~mm}(0.492$ and 0.182 in.), respectively. This very small specimen size would demand special techniques for testing. The two conventional methods employed in J-R testing for monitoring crack growth during the test are unloading compliance and potential drop. Unloading compliance (UC) requires periodic partial unloadings of the specimen to determine the specimen compliance, from which the crack length and extension are calculated. This technique demands high accuracy for the measurement of the load-displacement data in order to determine the correct compliance values, and hence crack extensions. The second method, potential drop (PD), imposes a constant current across the specimen and measures the changing resistance of the unbroken ligament as the crack extends. This resistance change is used to determine the crack length. Less accurate displacement measurements are necessary than with UC testing, as the displacement is used only to calculate the energy required for crack extension, and this calculation is less sensitive to the displacement measurement than are the compliance measurements necessary for UC determination of crack growth. UC measurements for irradiated specimens have been conducted 
frequently at ORNL, and much more experience had been accumulated in testing unirradiated material with UC than with PD. However, the small specimen size precluded the use of conventional displacement measuring methods available at ORNL, so a different method was developed.

The UC technique requires accurate measurement of the specimen displacements. The usual technique for measuring the displacements along the specimen load line is to fabricate the specimen with a cutout that allows a clip gage to be inserted between the loading pin holes to the load line, where it seats on knife edges fastened along the load line on the sides of the notch cutout. The disk compact specimen is quite small, and there is not sufficient room between the loading holes for a cutout to allow a clip gage to be inserted to the load line. Therefore, grooves were machined on the outer edge of the specimen above and below the loading holes (see Fig. 1) so that the load line displacement could still be measured directly, but outside the loading holes rather than in between them. The grooves had an included angle of $60^{\circ}$, with a depth of $0.5 \mathrm{~mm}(0.020 \mathrm{in.})$ and a root radius of $0.05 \mathrm{~mm}(0.002 \mathrm{in.})$. A robust and rugged yet highly accurate clip gage that could be handled by manipulators was designed. The gage included knife edges that would seat in the grooves. This clip gage, termed an "outboard" gage since it was attached outside of the loading holes, contained a central flexural beam on which four strain gages were attached for a fullbridge measurement of the strains and hence the displacement. Figure 1 shows the outboard gage attached to one of the disk compact specimens.

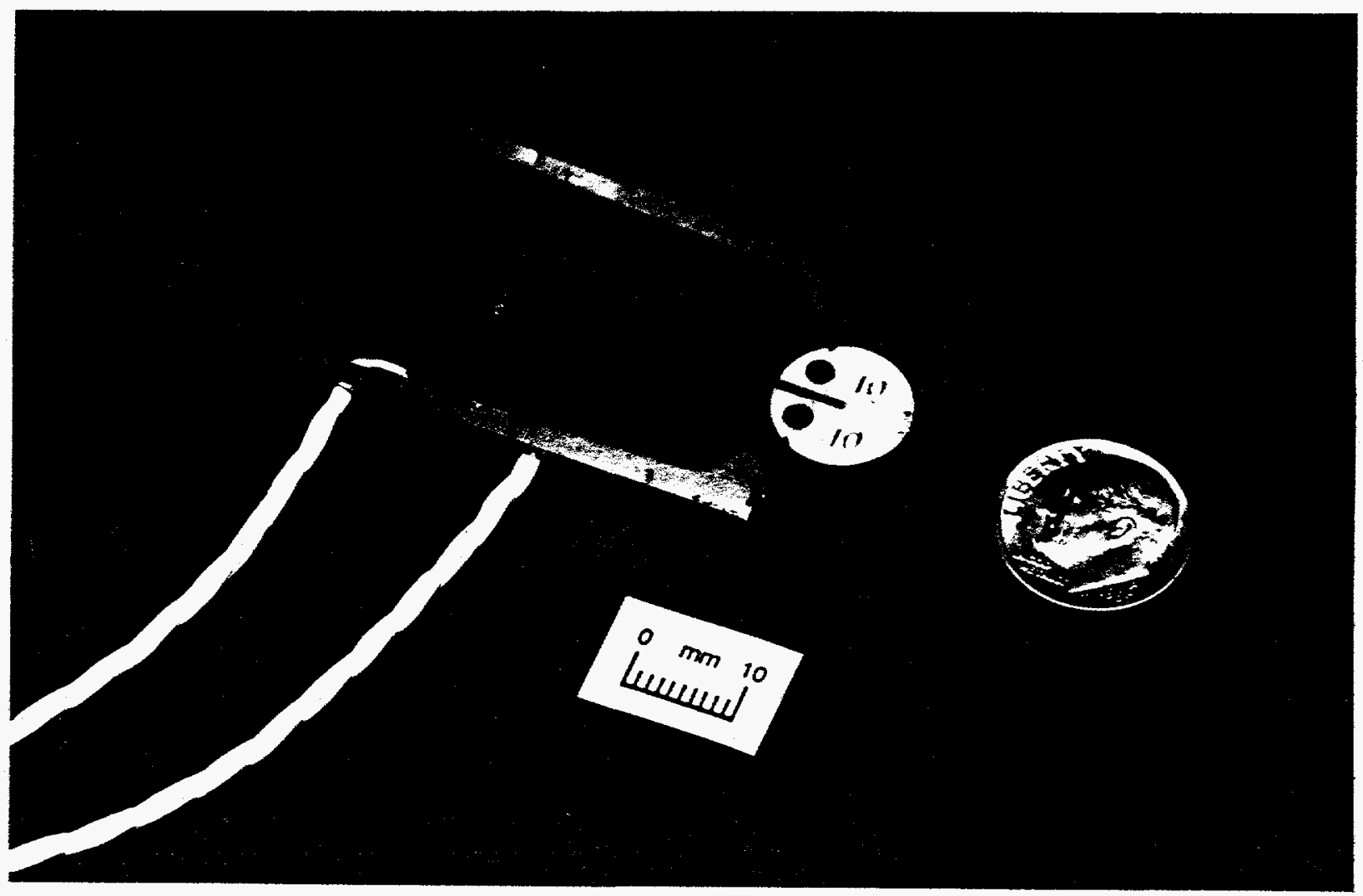

Fig. 1. The outboard clip gage seated on the disk compact specimen. The back end of the clip gage allows handling with a manipulator while providing overtravel protection. 
Initial trials showed that both the UC and the PD methods could be used to develop useful fracture toughness data from these small specimens [9]. As a result of the success of the laboratory trials, it was decided to use the unloading compliance technique for testing the irradiated specimens.

Most of the specimens were oriented for crack growth parallel to the rolling direction (T-L orientation). The specimens were precracked at room temperature prior to irradiation with a final maximum stress intensity of approximately $22 \mathrm{MPaVm}(20 \mathrm{ks} / \mathrm{in}$.$) . A chevron notch was used to assist$ crack initiation and maintain crack front straightness during precracking. The specimens were precracked to a nominal crack length to specimen width ratio $(a / W)$ value of 0.5 . The specimens were then side grooved $10 \%$ of their thickness on each side $\left(20 \%\right.$ total) with an included angle of $45^{\circ}$ and a root radius of $0.10 \mathrm{~mm}(0.004 \mathrm{in}$.$) . The side grooves would suppress the development of slant shear fracture.$

Filler pieces were inserted in the loading holes and in the notches to reduce disturbances in the flow of cooling water over the specimens in the capsule and to improve the uniformity of heat transfer across the specimens.

Capsules JP-18 and -19 completed their irradiations in October 1991, and capsule JP-17 completed its irradiation in February 1992 [3]. After disassembly of the capsules, the inserts in the individual specimens were pushed out of the loading holes using an arbor press and punch. The filler in the notch was removed with the aid of a hammer and a thinned screwdriver blade.

The disk compact specimen and the outboard clip gage have been successfully mounted in the load train of the servohydraulic test machine in the hot cell, using manipulators. No additional fixturing was required to align the specimen assembly with the grips so that the loading pins could be inserted. The pins were made with one end tapered and an offset block on the other end for handling with the manipulator. The clip gage was first attached to the specimen, and examined to be sure that the knife edges were seated in the grooves. The operator then grasped one arm of the clip gage with the manipulator and positioned the specimen in the load train. Inserting the pins through the clevis and loading holes was difficult, but was possible without needing special fixtures. No attempt has been made to attach the PD leads in the hot cell.

Tests were conducted in general accordance with American Society for Testing and Materials standards $E$ 813-89, Standard Test Method for $J_{1 c}$, A Measure of Fracture Toughness, and E 1152-87, Standard Test Method for Determining J-R Curves. The specimens were tested with a computer-controlled testing and data acquisition system [11]. Tests in the laboratory used an 89-kN capacity servohydraulic test machine. In the hot cell, a $445-\mathrm{kN}$ capacity servohydraulic testing machine with an $22-\mathrm{kN}$ load cell was used. All tests were run in strain control. Test temperatures from 90 to $250^{\circ} \mathrm{C}$ were maintained within $\pm 2{ }^{\circ} \mathrm{C}$ of the desired temperature with a split-box furnace that enclosed the specimen and the grips 
during the test. Temperature was monitored throughout the testing with a thermocouple that was held in contact with the specimen by a spring-loaded clip. Tensile data from specimens included in the capsules were used for calculations in the J-R analyses [12]. Estimated values were taken from literature data when necessary.

After testing, the specimens were heat tinted by placing them on a hot plate and heating them until a noticeable color change had occurred. The specimens were cooled to room temperature and then broken open. The initial and final crack lengths for the unirradiated specimens were measured with an optical measuring microscope. For the irradiated specimens, photographs of the fracture surfaces were fastened to a digitizing tablet to measure the crack lengths.

\section{RESULTS AND DISCUSSION}

The unirradiated specimens showed enormous crack-tip blunting before stable crack growth began. This resulted in gross changes in the specimen geometry, and so the crack length predictions were not very accurate. The J-R curve was much steeper than the calculated blunting line. In these cases, the data were used to calculate a blunting line. A straight line was fit by eye through the initial portion of the data points, and a second line was drawn parallel to the first but offset by an amount corresponding to a crack extension of $0.2 \mathrm{~mm}$. The candidate toughness value $J_{Q}$ value was then determined from the intersection of the data with this offset line. In cases where the data rose very steeply, the test was terminated before there was enough crack growth to cross the second exclusion line (drawn corresponding to a crack extension of $1.5 \mathrm{~mm}$ as defined in the ASTM standards). As a result, no tearing modulus value could be calculated. After irradiation the specimens behaved in a much more conventional manner. The data followed the calculated blunting line quite closely, so no additional construction was required. These specimens also showed good agreement between the measured and predicted final crack lengths.

The results of the testing are given in Table 1. The table also includes the tensile values used in the analyses. The critical stress intensities calculated from the candidate $\mathrm{J}$ values for the various alloys are summarized in Fig. 2 as a function of test temperature. The toughness of the austenitic steel is very high. In general, the toughness decreases as the test temperature increases, but remains very high.

Both before and after irradiation, the fracture toughness of the annealed material is generally very high $\left(\mathrm{K}_{j}>200 \mathrm{MPa} / \mathrm{m}\right)$ in the test temperature range. The toughness decreases slightly as the temperature increases, but remains very high, even after irradiation and testing at $250^{\circ} \mathrm{C}$. The EC316L shows only a slight decrease in toughness (about $50 \mathrm{MPa} / \mathrm{m}$ ) after irradiation. The J-R curves for the 
Table 1. Fracture toughness of EC316L

\begin{tabular}{|c|c|c|c|c|c|c|c|c|}
\hline Material & $\begin{array}{c}\text { Irradiation } \\
\text { temperature } \\
\left({ }^{\circ} \mathrm{C}\right)\end{array}$ & $\begin{array}{c}\text { Test } \\
\text { temperature } \\
\left({ }^{\circ} \mathrm{C}\right)\end{array}$ & $\stackrel{J}{J}\left(k J / m^{2}\right)$ & $\frac{K_{J}}{(M P a V m)}$ & $T$ & $\begin{array}{c}\sigma_{y} \\
(\mathrm{MPa})\end{array}$ & $\begin{array}{c}\sigma_{u} \\
\left(M P_{a}\right)\end{array}$ & $\begin{array}{c}E \\
(G P a)\end{array}$ \\
\hline $\begin{array}{c}\text { EC316L } \\
\text { Ann }\end{array}$ & $\begin{array}{l}\text { Unirradiated } \\
\text { Unirradiated } \\
\text { Unirradiated }\end{array}$ & $\begin{array}{r}22 \\
100 \\
200\end{array}$ & $\begin{array}{l}769 \\
889 \\
696\end{array}$ & $\begin{array}{l}385 \\
407 \\
353\end{array}$ & $\begin{array}{l}a \\
a \\
a\end{array}$ & $\begin{array}{l}276 \\
228 \\
186\end{array}$ & $\begin{array}{l}579 \\
503 \\
441\end{array}$ & $\begin{array}{l}193 \\
186 \\
179\end{array}$ \\
\hline $\begin{array}{c}\text { EC316L } \\
\text { Ann }\end{array}$ & $\begin{array}{l}90 \\
90 \\
90 \\
90 \\
90 \\
90\end{array}$ & $\begin{array}{r}25 \\
25 \\
25 \\
100 \\
100 \\
200\end{array}$ & $\begin{array}{l}775 \\
799 \\
751 \\
658 \\
575 \\
498\end{array}$ & $\begin{array}{l}387 \\
393 \\
381 \\
350 \\
327 \\
299\end{array}$ & $\begin{array}{r}109 \\
95 \\
150 \\
130 \\
92 \\
168\end{array}$ & $\begin{array}{l}621 \\
621 \\
621 \\
607 \\
607 \\
600\end{array}$ & $\begin{array}{l}689 \\
689 \\
689 \\
676 \\
676 \\
676\end{array}$ & $\begin{array}{l}193 \\
193 \\
193 \\
186 \\
186 \\
179\end{array}$ \\
\hline $\begin{array}{c}\text { EC316L } \\
\text { Ann }\end{array}$ & $\begin{array}{l}250 \\
250 \\
250 \\
250\end{array}$ & $\begin{array}{r}25 \\
100 \\
250 \\
250\end{array}$ & $\begin{array}{l}430 \\
390 \\
254 \\
351\end{array}$ & $\begin{array}{l}288 \\
269 \\
213 \\
251\end{array}$ & $\begin{array}{l}43 \\
39 \\
45 \\
62\end{array}$ & $\begin{array}{l}779 \\
772 \\
758 \\
600\end{array}$ & $\begin{array}{l}786 \\
779 \\
765 \\
648\end{array}$ & $\begin{array}{l}193 \\
186 \\
179 \\
179\end{array}$ \\
\hline EC316L Per & Unirradiated & 90 & 834 & 394 & $a$ & 228 & 510 & 186 \\
\hline EC316L Per & 90 & 90 & 697 & 360 & 169 & 607 & 676 & 186 \\
\hline
\end{tabular}




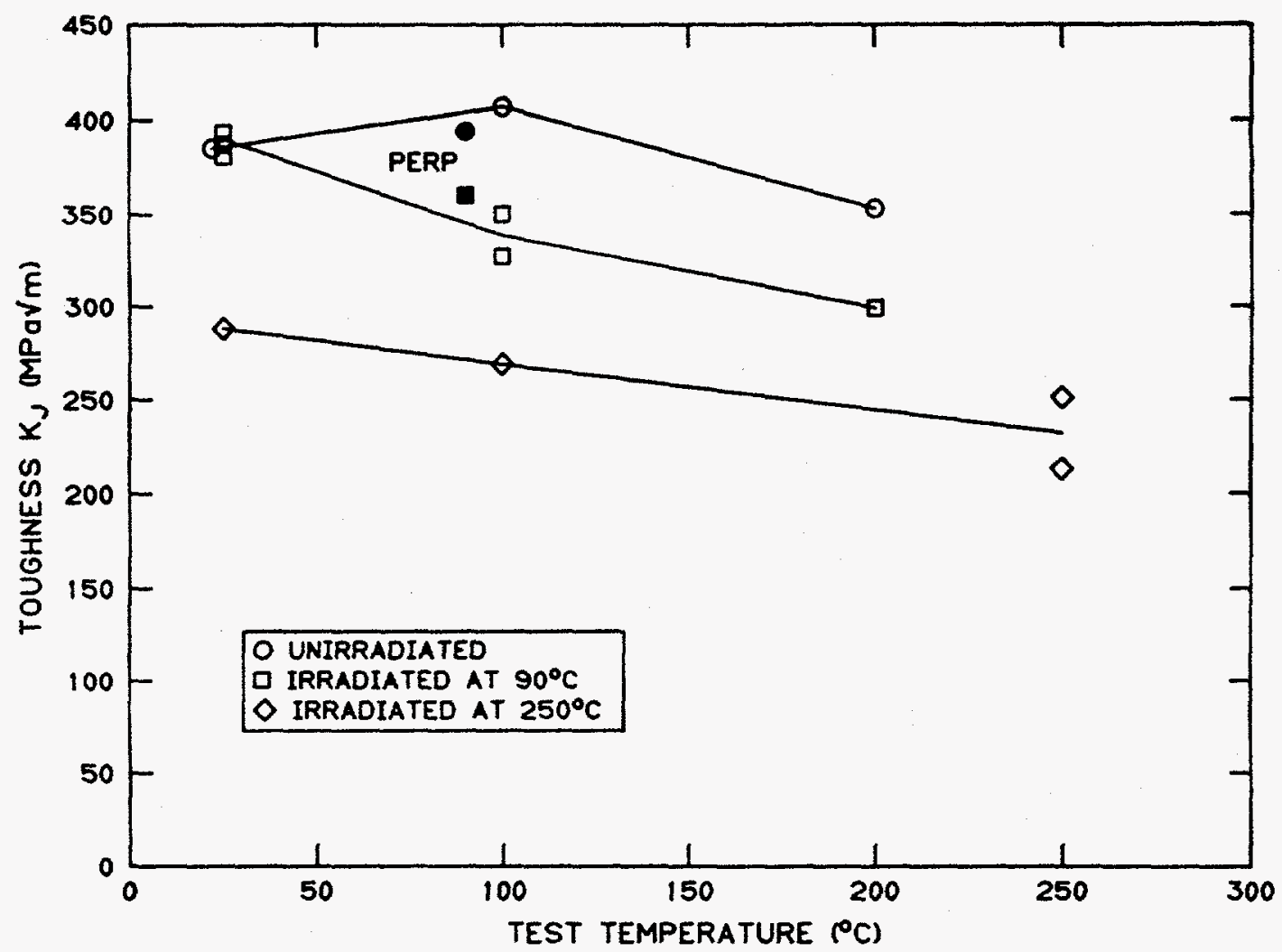

Fig. 2. Fracture toughness values for annealed EC316L. The two data points labeled PERP are for specimens oriented for crack growth perpendicular to the rolling direction.

EC316L specimens are shown in Fig. 3. After irradiation, the J-R curves have a lower slope, which reflects the lower values of tearing moduli given in Table 1 . The toughness level decreases with increasing test temperature.

The fracture toughness values obtained in these tests are in the upper range of previously reported data from a variety of austenitic stainless steels, reactor environments, and test methods $[1,2,13]$. These data show similar trends with irradiation as shown by other tests of EC316L using larger conventional rectangular compact specimens [14]. Similar tests with other austenitic stainless steels have also resulted in good agreement between the different specimen sizes and types [15]. This provides further evidence that the small disk compact specimen geometry can be used to generate useful fracture toughness data to show the effects of irradiation on the fracture toughness of these materials.

\section{CONCLUSIONS}

Small disk compact specimens (12.5 $\mathrm{mm}$ diam by $4.6 \mathrm{~mm}$ thick) have been successfully irradiated and tested. Specimens of EC316L austenitic stainless steel have been irradiated in HFIR to about 3 dpa at nominal irradiation temperatures of 90 or $250^{\circ} \mathrm{C}$. Irradiation reduces the fracture toughness. Irradiation 

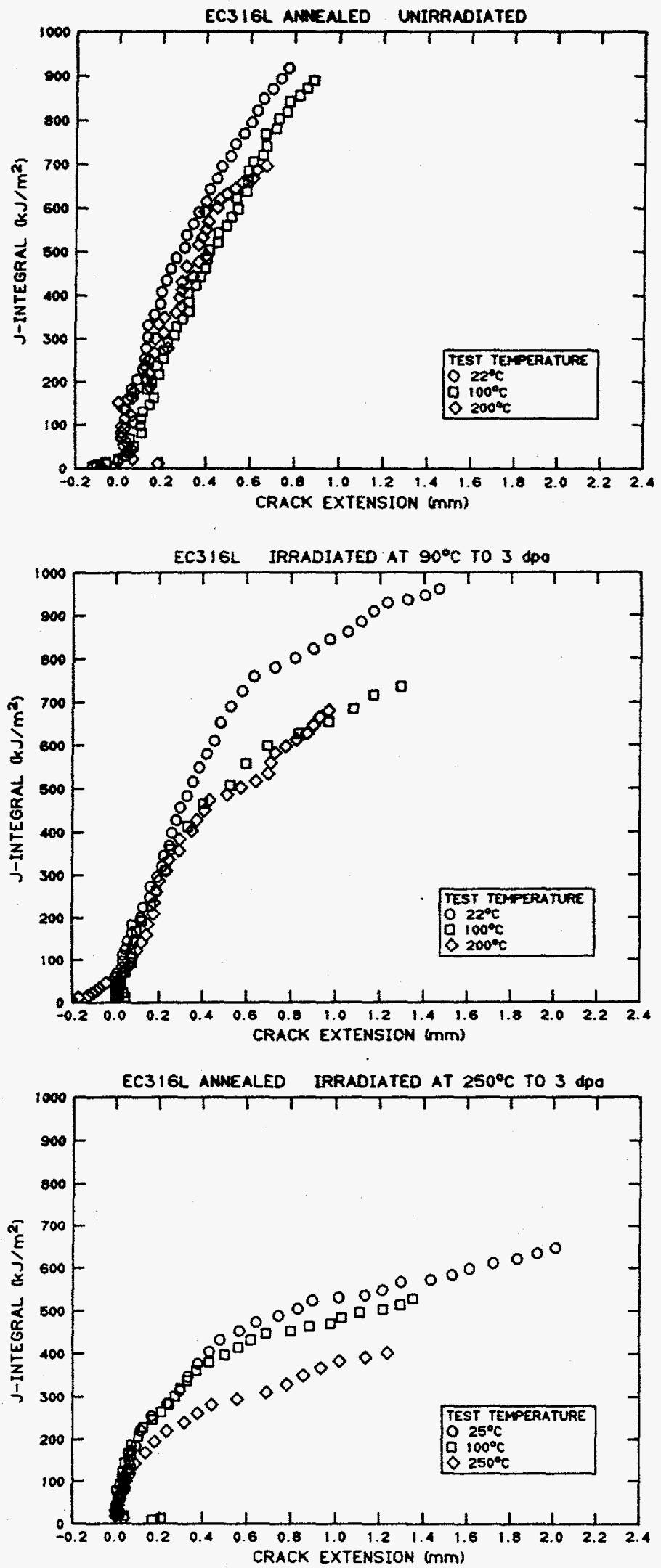

Fig. 3. J-R curves for annealed EC316L material in the unirradiated condition (top), and after irradiation to $3 \mathrm{dpa}$ at $90^{\circ} \mathrm{C}$ (middle) and $250^{\circ} \mathrm{C}$ (bottom). 
at $250^{\circ} \mathrm{C}$ is more damaging than at $90^{\circ} \mathrm{C}$. The fracture toughness decreases with increasing test temperature. These results show that the small disk compact specimen can provide useful fracture toughness data.

\section{ACKNOWLEDGMENTS}

Research sponsored by the Office of Fusion Energy, U.S. Department of Energy, under contract DEAC05-84OR21400 with Martin Marietta Energy Systems, Inc. The clip gage was designed and fabricated by John A. Shepic, Lakewood, CO 80228 . The manuscript was prepared by J. L. Bishop.

\section{REFERENCES}

1. G. R. Odette and G. E. Lucas, J. Nucl. Mater., Vol. 179-181, 1991, p. 572.

2. G. R. Odette and G. E. Lucas, J. Nucl. Mater., Vol. 191-194, 1992, p. 50.

3. A. W. Longest, D. W. Heatherly, K. R. Thoms, and J. E. Corum, "Design and Fabrication of HFIR-FE-JP Target Irradiation Capsules," Fusion Reactor Materials Semiannual Progress Report for Period Ending March 31, 1991, DOE/ER-0313/10, 1991, p. 3.

4. A. W. Longest, D. W. Heatherly, J. E. Wolfe, K. R. Thoms, and J. E. Corum, "Fabrication and Irradiation of HFIR-MFE-JP-17, -18, and -19 Target Irradiation Capsules," Fusion Reactor Materials Semiannual Progress Report for Period Ending September 30, 1991, DOE/ER-0313/11, 1992, p. 30.

5. A. W. Longest, D. W. Heatherly, K. R. Thoms, and J. E. Corum, "Fabrication and Irradiation of HFIR-FE-P-17, -18, and -19 Target Irradiation Capsules," Fusion Reactor Materials Semiannual Progress Report for Period Ending March 31, 1992, DOE/ER-0313/12, 1992, p. 24.

6. J. E. Pawel, D. J. Alexander, M. L. Grossbeck, A. W. Longest, A. F. Rowcliffe, G. E. Lucas, S. Jitsukawa, A. Hishinuma, and K. Shiba, "Fracture Toughness of Candidate Materials for ITER First Wall, Blanket, and Shield Structures," Fusion Reactor Materials Semiannual Progress Report for Period Ending September 30, 1993, DOE/ER-0313/15, 1992, p. 173.

7. D. J. Alexander, J. E. Pawel, M. L. Grossbeck, A. F. Rowcliffe, and K. Shiba, "Fracture Toughness of Irradiated Candidate Materials for ITER First Wall/Blanket Structures," Fusion Reactor Materials Semiannual Progress Report for Period Ending March 31, 1994, DOE/ER-0313/16, 1994, in press.

8. D. J. Alexander, J. E. Pawel, M. L. Grossbeck, A. F. Rowcliffe, and K. Shiba, "Fracture Toughness of Irradiated Candidate Materials for ITER First Wall/Blanket Structures," Effects of Radiation on Materials, 17th International Symposium, ASTM STP 12XX, D. S. Gelles, R. K. Nanstad, A. S. Kumar, and E. A. Little, eds., American Society for Testing and Materials, Philadelphia, 1995, in press.

9. D. J. Alexander, "Fracture Toughness Measurements with Subsize Disk Compact Specimens, " in Small Specimen Test Techniques Applied to Nuclear Reactor Vessel Thermal Annealing and Plant Life Extension, ASTM STP 1204, W. R. Corwin, F. M. Haggag, and W. L. Server, eds., American Society for Testing and Materials, Philadelphia, 1993, p. 130. 
10. C. Elliot, M. Enmark, G. E. Lucas, G. R. Odette, and A. Rowcliffe, "Development of Disc Compact Tension Specimens and Test Techniques for HFIR Irradiations," J. Nucl. Mater., Vol. 179-181, 1991, p. 434.

11. R. K. Nanstad, D. J. Alexander, R. L Swain, J. T. Hutton, and D. L. Thomas, "A Computer-Controlled Automated Test System for Fatigue and Fracture Testing," in Applications of Automation Technology to Fatigue and Fracture Testing, ASTM STP 1092, A. A. Braun, N. E. Ashbaugh, and F. M. Smith, eds., American Society for Testing and Materials, Philadelphia, PA, 1990, p. 7.

12. J. E. Pawel, Oak Ridge National Laboratory, personal communication, 1994.

13. G. E. Lucas, J. Nucl. Mater., Vol. 206, 1993, p. 287

14. M. I. de Vries, ECN Petten, The Netherlands, personal communication, 1994.

15. S. Jitsukawa, Japan Atomic Energy Research Institute, Tokai-Mura 319-11 Japan, this proceedings. 